8. Про затвердження військово-адміністративного поділу території України : указ Президента України від 05.02.2016 № 39/2006. Офіційний вісник Украӥни. 2016. № 12. Ст. 500.

9. Про Річну національну програму під егідою Комісії Україна - НАТО на 2019 рік: указ Президента України від 10.04.2019 № 117/2019. Офіційний вісник України. 2019. № 31. Ст. 1109.

10. Про затвердження Положення про використання повітряного простору України : постанова Кабінету Міністрів України від 06.12.2017 № 954. Офічійиий вісник України. 2017. № 101. ст. 3118.

11. Про затвердження Авіаційних правил України «Загальні правила польотів у повітряному просторі України»: наказ Державної авіаційної служби України та Міністерства оборони України від 06.02.2017 р. № 66/73. Офіиійний вісник України. 2017. № 45. Ст. 1416.

12. Про створення об'єднаної цивільно-військової системи організації повітряного руху України : постанова Кабінету Міністрів України від 19.07.1999 № 1281. Офіuійний вісник України. 1999. № 29. ст. 1484.

13. Про затвердження політики власності Державного підприємства обслуговування повітряного руху України: наказ Міністерства інфраструктури України від 18.12.2018 № 641. Інформаційно-правові системи Ліга: Закон. URL: https://ips.ligazakon.net/document/FN049111?an=1.

УДК 342.951:004.5

DOI https://doi.org/10.32844/2618-1258.2019.6.25

ВЕСЕЛОВА Л.Ю.

\title{
АДМІНІСТРАТИВНО-ПРАВОВІ ЗАХОДИ У СФЕРІ ЗАБЕЗПЕЧЕННЯ КІБЕРБЕЗПЕКИ
}

У статті констатується, що адміністративно-правові засоби забезпечення кібернетичної безпеки реалізуються відповідним адміністративно-правовим механізмом забезпечення кібернетичної безпеки, низкою адміністративно-правових норм і здійснюваних на їх основі спеціальних юридичних дій у цій сфері. Своєю чергою адміністративно-правові заходи забезпечення кібернетичної безпеки $\epsilon$ діяльною частиною нормативно визначених адміністративно-правових засобів. Тобто більш широким юридичним терміном $є$ «адміністративно-правові засоби забезпечення кібернетичної безпеки», що реалізуються певними нормативно передбаченими способами й прийомами у практичній діяльності суб'єктів національної системи кібернетичної безпеки. У статті надається класифікація заходів адміністративно-правового забезпечення кібернетичної безпеки. Зазначається, що примусові заходи щодо адміністративно-правового забезпечення кібербезпеки мають бути обов'язково законодавчо унормовані. Зазначається, що без відповідного закріплення примусових заходів щодо адміністративно-правового забезпечення кібербезпеки в акті законодавства як елементу механізму адміністративно-правового забезпечення кібербезпеки вони не можуть бути використані. Аналізуються підходи вчених щодо класифікації заходів адміністративного примусу. Дослідивши теоретичні засади, адміністративно-правові заходи у статті пропонується розглядати за трьома групами: заходи адміністративного стягнення (штраф, конфіскація, виправні роботи тощо); заходи адміністративного припинення (особисте затримання, позбавлення спеціального права тощо); адміністративно-попереджувальні заходи (огляд, перевірка документів, вимога припинення окремих дій тощо). Зазначається, що кожна із груп заходів має своє специфічне призначення, але одночасно наділені також спільними характеристиками, що визначаються державно-владним характером та є обов'язковими для виконання. Автор статті зазначає, що в межах до-

(C ВЕСЕЛОВА Л.Ю. - кандидат юридичних наук, доцент кафедри адміністративної діяльності поліції (Одеський державний університет внутрішніх справ) 
слідження механізму адміністративно-правового забезпечення кібернетичної безпеки України, важливим $\epsilon$ визначення поняття заходів адміністративно-правового забезпечення кібернетичної безпеки, що пропонується розуміти як законодавчо визначену сукупність взаємопов'язаних організаційно-правового й спеціального характеру заходів державно-владного впливу суб'єктів національної системи кібернетичної безпеки, спрямованих на забезпечення кібернетичної безпеки людини, суспільства та держави.

Ключові слова: національна система, заходи адміністративного стягнення, заходи адміністративного припинення адміністративно-попереджувальні заходи, адміністративний примус.

The article states that the administrative and legal remedies for cybersecurity are implemented by the appropriate administrative and legal mechanism for ensuring cybersecurity, a number of administrative and legal norms and special legal actions in this area implemented on their basis. In turn, administrative and cyber security measures are an active part of the regulatory legal framework. That is a broader legal term is "administrative and legal means of cybersecurity", which is implemented by certain regulatory methods and techniques in the practical activity of the subjects of the national cybersecurity system. The article provides a classification of cyber security administrative measures. It is stated that compulsory measures for the administrative and legal support of cybersecurity should be compulsory by law. It is noted that without appropriate enforcement of cyber security enforcement measures in an act of legislation, as an element of the cybersecurity administrative legal framework, they cannot be used. Scientists' approaches to classification of administrative coercion measures are analyzed. Having examined the theoretical principles, the article proposes to consider the administrative-legal measures in three groups: measures of administrative punishment (fine, confiscation, corrective works, etc.); measures of administrative termination (personal detention, deprivation of special right, etc.); administrative and preventive measures (review, document verification, request for termination of individual actions, etc.). It is noted that each of the groups of measures has its specific purpose, but at the same time it is also endowed with common characteristics that are determined by the state-governmental nature and are obligatory for implementation. The author of the article notes that within the framework of the study of the cyber security administrative mechanism of Ukraine, it is important to define the concept of cybersecurity administrative measures, which is proposed to be understood as a legally defined set of interrelated organizational and legal and the special nature of measures of state-power influence of subjects of the national cybersecurity system aimed at providing cybersecurity of man, society and the state.

Key words: national system, measures of administrative punishment, measures of administrative termination administrative-preventive measures, administrative coercion.

Вступ. Поняття «адміністративно-правові заходи» вченими-адміністративістами досліджується достатньо часто, 3 наголосом як на теоретичних аспектах зазначених заходів, так і 3 урахуванням особливостей предмету й напрямів їх застосування, зокрема, це праці таких науковців, як Д.К. Бахрах, Ю.П. Битяк, I.I. Веремеєнко, В.М. Гаращук, В.Д. Гурвич, В.Я. Настюк, B.С. Севрюгін та інші. Насамперед звертає на себе увагу розбіжність у використанні термінології. Низка вчених для позначення адміністративно-правового механізму через використовувані способи чи прийоми в одних випадках використовують юридичний термін «адміністративно-правові заходи», в інших - «адміністративно-правові засоби». В деяких роботах ці терміни використовуються паралельно і не розмежовується їх зміст, хоча етимологічне пояснення слів «засіб» і «захід» є досить близьким за значенням. Потрібно зазначити, що термін «засіб» у сучасній українській мові пояснюється як прийом, спеціальна дія, що уможливлює здійснення, досягнення чого-небудь, знаряддя в якій-небудь справі; а «захід» - як абстрагована опредмечена дія; сукупність дій, що мають на меті здійснення чого-небудь [1, с. 356-363]. 3 огляду на предмет дослідження щодо адміністративно-правового забезпечення кібербезпеки доречним $€$ з'ясування сутності зазначених термінів, а також визначення системи цільових адміністративно-правових заходів у сфері кібербезпеки. 
Свій внесок у розуміння правових засобів зробили вчені: С.С. Алексєєв, В.М. Горшеньов, Д.А. Керімов, О.Г. Лук'янова, О.В. Малько, П.М. Рабінович, Р.О. Халфіна та низка інших.

Постановка завдання. Метою статті $\epsilon$ - шляхом дослідження механізму адміністративно-правового забезпечення кібербезпеки визначити поняття заходів адміністративно-правового забезпечення кібербезпеки.

Результати дослідження. У юридичній науці поняття «правові засоби» переважно характеризується сукупністю певних елементів: механізму правового регулювання; способів правової організації; нормативно-владного упорядкування певних груп суспільних відносин; виконання функцій права.

Тобто правовими засобами є норми права, суб'єктивні права й обов'язки, акти здійснення суб'єктивних прав та обов'язків, інші акти правозастосування, угоди тощо [2, с. 363].

У теорії адміністративного права під правовими засобами розуміють систему адміністративно-правових норм, яка розглядається з погляду її функціонального призначення - як спосіб вирішення конкретних соціально значимих державно-управлінських завдань. Адміністративно-правові засоби становлять використовувану у зв'язку зі здійсненням державного управління частину відомих вітчизняній теорії і практиці правового регулювання правових засобів. Вони володіють усіма їх загальними властивостями й рисами [3, с. 56].

О.В. Дьяченко тлумачить адміністративно-правові засоби боротьби з корисливими правопорушеннями як норми адміністративного права, а також урегульовані ними взаємопов'язані прийоми, заходи, що передбачають викорінення таких деліктів [4, с. 18].

Узагальнюючи зазначене, можемо констатувати, що адміністративно-правові засоби забезпечення кібербезпеки реалізуються відповідним адміністративно-правовим механізмом забезпечення кібербезпеки, низкою адміністративно-правових норм і здійснюваних на їх основі спеціальних юридичних дій у цій сфері. Своєю чергою адміністративно-правові заходи забезпечення кібербезпеки $є$ діяльною частиною нормативно визначених адміністративно-правових засобів. Тобто більш широким юридичним терміном $€$ «адміністративно-правові засоби забезпечення кібербезпеки», що реалізуються певними нормативно передбаченими способами й прийомами у практичній діяльності суб'єктів національної системи кібербезпеки.

Водночас зазначене зумовлює застосування суб'єктами національної системи кібербезпеки примусових заходів правової охорони, що $є$ невіддільним показником функціонування права й держави, не виключаючи й демократичної, правової країни.

Але сьогодні примус в Україні відзначається не стільки поширеністю, скільки потенційністю, абсолютністю його форм. Ним оперують, коли вичерпані всі можливі заходи переконання, й іншим чином не вдається запобігти протиправній поведінці [3, с. 53].

Передусім потрібно зазначити, що застосування суб'єктами національної системи кібербезпеки владних заходів здійснюється за особливих умов. У межах переконання, на відміну від заохочувальних та роз'яснювальних, реалізація примусу є можливою винятково на підставі, в межах повноважень та у спосіб, що передбачені законами України (ч. 2 ст. 6, ч. 2 ст. 19, п. п. 9, 12 і 22 Ч. 1 ст. 92 Конституції України) [5]. Конституційно-правовий принцип є ключовим, що виключає можливість примушення громадян робити те, що не визначено законодавством (ч. I ст. 19 Основного Закону України) [5]. Тобто примусові заходи щодо адміністративно-правового забезпечення кібербезпеки мають бути обов'язково законодавчо унормовані. I без відповідного їх закріплення в акті законодавства як елементу механізму адміністративно-правового забезпечення кібербезпеки вони не можуть бути використані.

Свого часу Л.М. Розін заходи адміністративного примусу розділяв на п’ять груп [6, с. 182-189]. Подібну класифікацію адмінпримусу підтримували науковці Б.В. Росінський, Ю.М. Старилов [7, с. 464-467], П.В. Діхтієвський [8, с. 46-47]. Хоча їх думку не всі вчені адміністративісти поділяють. Вони нічим не обгрунтовують якісно нові, відмінні від попередньо розглянутих видів заходів адміністративного примусу, хоча й відокремлюють додаткові від загальновизнаних - заходи адміністративно-процесуального забезпечення від заходів відновлення порушених прав. Проте проведене ретельне дослідження не виявило достатніх підстав для виокремлення цих груп у структурі заходів адміністративного примусу [3, с. 65].

Дискусійними залишаються підходи вітчизняних адміністративістів і зараз. Перші намагання класифікації пов'язувалися з виділенням адміністративних стягнень, тобто покаранням винних за вчинення адміністративного правопорушення, а також вжиттям заходів адміністративного запобігання, тобто попередження і припинення адміністративних деліктів [9]. 
Адміністративно-правове забезпечення кібербезпеки в державі потребує реального та ефективного втілення у практику суб'єктами національної системи кібербезпеки, визначеного державою правового механізму, застосовуючи, за необхідності, адміністративний примус та відповідні адміністративно-правові заходи. Зазначимо також, що важливим принципом адміністративно-правового забезпечення кібербезпеки залишається невідворотність впливу на законність, правопорушника та справедливість. За такого підходу застосовуються адміністративно-правові заходи лише як визначена державою правова дія на явні та конкретні правопорушення. В одних випадках припиняється конкретна неправомірна дія, поведінка, образ дій, в інших - підставою для застосування цих заходів виступає конкретний адміністративний вчинок (проступок), наприклад, дрібне хуліганство, систематичні порушення закону, антигромадський спосіб життя тощо [10, с. 54]. Поряд 3 цим існує окрема юридична думка щодо можливого застосування адміністративно-правових заходів як за наявності, так і за відсутності правопорушення [11, с. $15-22 ; 12$, с. $78-89]$.

Незважаючи на дискусійність, вважаємо важливим відзначити, що адміністративно-правові заходи примусу є засобом забезпечення кібербезпеки, а їх головне призначення у примусовому припиненні протиправних дій, що стосуються незаконного втручання в комп'ютерні та телекомунікаційні системи та порушення при цьому прав та свобод людини.

Т.О. Коломоєць $[13,105-110]$ та Р.С. Мельник $[14$, с. 5, 6] внесли свої правки до класифікації заходів адміністративного примусу, виділяючи примусові заходи, що пов'язані або не пов'язані з відповідальністю. При цьому заходи адміністративного примусу, що не пов'язані з відповідальністю, розділяються на заходи адміністративного попередження й припинення, а тому ця група є неоднорідною, що й ускладнює реалізацію заходів, які є різними за характером і призначенням.

Методологічною основою нашого дослідження варто все ж обрати підходи вчених, за якими класифікація заходів адміністративного примусу базується на їх поділі залежно від мети застосування на групи запобігання, припинення й відповідальності. Такий підхід $є$ притаманним більшості українських учених-адміністративістів (Ю.П. Битяк, В.В. Зуй [15, с. 78], О.М. Бандурка [16, с. 18-19], Є.В. Додін [17, с. 112, 138], Л.В. Коваль [18, с. 116-121], В.К. Колпаков, А.Т. Комзюк [19, с. 198$]$ та інші.

На нашу думку, зазначений підхід дає можливість достатньо послідовно і ефективно забезпечувати кібербезпеку на основі саме механізму адміністративно-правового регулювання. Насамперед застосовуються заходи профілактичного характеру на основі попередження правопорушення, що найменше обмежує можливі сфери інтересів та діяльності об'єкта регулювання, i лише після цього $є$ обгрунтованим використання заходів припинення, які лише тимчасово спричинюють негативні правові наслідки щодо цього об'єкта. Крім того, заходи припинення не такою мірою спричинюють правові наслідки, як заходи відповідальності, за наявності логічного завершення правопорушення. У системі адміністративно-правового забезпечення кібербезпеки це щонайменше дозволяє більш економно використовувати матеріальні ресурси й не допускати необгрунтованого обмеження прав і свобод громадян.

Такий підхід до класифікації заходів адміністративного примусу сформулював свого часу M.I. Єропкін, визначивши при цьому певний алгоритм: першочергове використання профілактичних й попереджувальних прийомів, а вже потім адміністративні стягнення, як більш суворі заходи примусу [20, с. 60-68].

Таким чином, дослідивши теоретичні засади, адміністративно-правові заходи доречно розглядати за трьома групами: заходи адміністративного стягнення (штраф, конфіскація, виправні роботи тощо); заходи адміністративного припинення (особисте затримання, позбавлення спеціального права тощо); адміністративно-попереджувальні заходи (огляд, перевірка документів, вимога припинення окремих дій тощо).

Кожна із груп заходів має своє специфічне призначення, але одночасно наділені також спільними характеристиками, що визначаються державно-владним характером та є обов'язковими для виконання.

Зокрема, заходи адміністративного стягнення мають характер покарання, а попереджувальні адміністративно-правові заходи та заходи припинення переслідують загальну мету - профілактику правопорушень, зокрема і щодо сфери кібербезпеки. При цьому заходи припинення та адміністративно-попереджувальні заходи зазвичай є притаманними переважній частині державних регуляторів. Що ж стосується заходів адміністративного стягнення, то лише окремі органи влади наділяються законодавством такими повноваженнями. Зазначене формує додатковий до- 
слідницький інтерес щодо предмету і буде розглянуто в межах розгляду адміністративно-правового статусу суб'єктів національної системи кібербезпеки.

Висновки. Таким чином, в межах дослідження механізму адміністративно-правового забезпечення кібербезпеки України важливим $є$ визначення поняття заходів адміністративно-правового забезпечення кібербезпеки, що пропонується розуміти як законодавчо визначену сукупність взаємопов'язаних організаційно-правового й спеціального характеру заходів державно-владного впливу суб'єктів національної системи кібербезпеки, спрямованих на забезпечення кібербезпеки людини, суспільства та держави.

\section{Список використаних джерел:} 2002. $992 \mathrm{c}$.

1. Тлумачний словник української мови / За ред. проф. В.С. Калашника. Харків : Прапор,

2. Комаров С.А., Малько А.В. Теория государства и права. Москва : Норма, 2000. 448 с.

3. Галинська К.Ю. Адміністративно-правове забезпечення інформаційного правопорядку в Україні : дис. ... канд. юрид. наук : 12.00.07. Київ, 2016. 188 с.

4. Дьяченко А.В. Административно-правовые средства борьбы с корыстными правонарушениями : дис.. канд. юрид. наук : 12.00.07 / Украинская юридическая академия. Харків, 1 992. $219 \mathrm{c}$.

5. Конституція України від 28 червня 1996 р. Відомості Верховної Ради України. 1996. № 30. Ст. 141.

6. Розин Л.М. Проблемы классификации мер административного принуждения. Управление и право. 1982. Вып. 7. С. 182-189.

7. Бахрах Д. Н., Россинский Б. В., Старилов Ю. Н. Административное право: Учебник для вузов. Москва: Норма, 2004. 768 с.

8. Дихтиевський П. В. Административно-правовое принуждение в механизме обеспечения личной безопасности : автореф. дис... док. юрид. наук : 12.00.14 / Московский университет внутренних дел. Москва, 2004. 63 с.

9. Про Національну поліцію: Закон України від 02 липня 2015 р. № 580-VIII. Відомості Верховної Ради України. 2015. № 40-41. Ст. 379.

10. Севрюгин В.Е. Проблемы административного права : учебное пособие. Тюмень : ТВШ МВД РФ, ТГУ. 1994. 110 с.

11. Безсмертний Є.О. Адміністративно-запобіжні заходи, що застосовуються органами внутрішніх справ : дис. к.ю.н. : 12.00.07 / Універсітете внутрішніх справ. Харків, 1997. 140 с.

12. Административное право Украины : учеб. для студентов высш. учеб. заведений юрид. спец. / Под ред. проф. Ю.П. Битяка. Харьков : Право, 2003. 576 с.

13. Коломоєць Т. Класифікація заходів адміністративного примусу. Право Украйни. 2003. № 6. C. $105-110$.

14. Мельник Р.С. Забезпечення законності застосування заходів адміністративного примусу, не пов'язаних з відповідальністю : автореф. дис... канд. юрид. наук : 12.00 .07 / Національний університет внутрішніх справ. Харків, 2002. 19 с.

15. Битяк Ю.П., Зуй В.В. Адміністративне право України : конспект лекцій. Харків : Нац. юрид. акад. України, 1996. 160 с.

16. Бандурка О.М. Заходи адміністративного припинення в діяльності міліції: дис. ... канд. юрид. наук : 12.00 .07 / Харківська юридична академія. Харків, 1994. 158 с.

17. Додин Е.В. Акты санкционированного вмешательства в сфере торгового мореплавания : учеб. пособ. Одесса : Юрид. лит., 2001. 152 с.

18. Коваль Л.П. Адміністративне прав : курс лекцій. Київ: Вентурі, 1996. 208 с. 1999. $36 \mathrm{c}$.

19. Колпаков В.К. Адміністративне право України: Підручник. Київ : Юрінком Інтер.

20. Еропкин М.И. О классификации мер административного принуждения. Bonросы административного права на современном этапе. Москва : госюриздат, 1963. С. 60-68. 